\title{
PENINGKATAN AKTIVITAS DAN HASIL BELAJAR IPA MELALUI METODE KOOPERATIF TIPE JIGSA WPADA SISWA KELAS VIII-1 SMP NEGERI 3 TEBING TINGGI
}

\author{
Mangatur Silitonga
}

Surel: mangatur.sltg@gmail.com.

\begin{abstract}
This aim of this research is to improve learning result on science subject through cooperativejigsaw method of jigsaw type. This classroom action researchconducted by 2 cycles of the four phases: planning, implementation, observation, reflection. The subjects were students from class VIII-1 SMP Negeri 3 Tebing Tinggi which amounted to 37 students. This study used a qualitative descriptive analysis technique. The results showed that the use of the cooperative methodof jigsaw type inscience subjects can improve student learning result characterized by increased mastery learning students, namely the first cycle $(72,97 \%)$, cycle II $(89,18 \%)$ and complete learn the clasical equal to $89,18 \%$.
\end{abstract}

Key words: Jigsaw, cooperative, science

\begin{abstract}
ABSTRAK
Penelitian ini bertujuan untuk meningkatkan hasil belajar siswa mata pelajaran IPA melalui metode kooperatif tipe jigsaw. Penelitian tindakan kelas ini dilaksanakan sebanyak 2 siklus dengan empat tahapan yaitu: perencanaan, pelaksanaan, observasi, refleksi. Subjek penelitian ini adalah siswa kelas VIII-1 SMP Negeri 3Tebing Tinggi sebanyak 37 siswa. Penelitian ini menggunakan teknik analisis dekriptif kualitatif. Hasil penelitian menunjukkan bahwa penggunaan metode kooperatif tipe jigsaw dapat meningkatkan hasil belajar siswa pada mata pelajaran IPA yang ditandai dengan peningkatan ketuntasan belajar siswa, yaitu siklus I $(72,97 \%)$, siklus II $(89,18 \%)$ dan dinyatakan berhasil secara klasikal $89,18 \%$.
\end{abstract}

Kata Kunci: Jigsaw, kooperatif, IPA.

\section{PENDAHULUAN}

Untuk meningkatkan mutu pendidikan dan pengajaran salah satunya adalah dengan memilih strategi atau cara dalam menyampaikan materi pelajaran agar diperoleh peningkatan hasil belajar siswa khususnya pelajaran IPA. IPA adalah pengetahuan manusia tentang alam yang diperoleh alam dengancara yang terkontrol (Muslichah, 2006: 7). Perkembangan dari bidang IPA tidak mungkin terjadi bila tidak disertai dengan peningkatan mutu pendidikan IPA. Pembelajaran IPA merupakan proses membelajarkan subjek didik dalam mempelajari peristiwa yang terjadi di alam ini melalui serangkaian proses ilmiah sehingga tercapai tujuan pembelajaran yang sudah ditetapkan. Berdasarkan pengertian-pengertian di atas maka dapat disimpulkan bahwa pembelajaran IPA adalah membelajarkan siswa untuk memahami hakikat IPA (proses dan produk serta aplikasinya) mengembangkan sikap ingin tahu, 
keteguhan hati, ketekunan dan sadar akan nilai-nilai yang ada di dalam masyarakat serta pengembangan ke arah sikap yang positif.

Salah satu masalah pokok dalam pembelajaran IPA pada pendidikan formal di Indonesia dewasa ini adalah masih rendahnya daya serap dan pemahaman siswa terhadap materi pelajaran IPA. Pemahaman IPA senantiasa dipandang atau dirasakan sukar, baik oleh orang yang belajar dan tidak jarang juga oleh pengajarnya padahal IPA adalah pengtahuan alam yang ada pada kehidupan sehari-hari. Tingkat pemahaman IPA seorang siswa lebih dipengaruhi oleh siswa itu sendiri. Sedangkan pembelajaran IPA merupakan usaha membantu siswa mengkontruksi pengetahuan melalui proses.

Berdasarkan survey awal yang telah dilakukan di SMP Negeri 3 Tebing Tinggi khususnya siswa kelas VIII-1, dapat dikatakan hasil belajar siswa relatif kurang memuaskan. Hal ini terbukti dari rendahnya rata-rata nilai ulangan harian siswa yaitu 70,5. Dari 37 siswa, hanya 23 siswa yang memenuhi nilai ketuntasan belajar (nilai 70) dan masih terdapat 14 siswa yang tidak memenuhi nilai ketuntasan. Sehingga presentase siswa yang lulus hanya $62,16 \%$ dan masih terdapat $37,84 \%$ siswa yang mendapat nilai dibawah nilai ketuntasan.

Segala upaya yang dilakukan seorang guru dalam proses pembelajaran dapat di ketahui hasilnya melalui penilaian proses dan penilaian hasil. Hasil belajar dapat tercapai jika siswa mampu melakukan tugasnya sesuai dengan kompetensi dasar yang di tandai tercapainya indikator-indikator. Hasil belajar siswa pada hakikatnya adalah perubahan tingkah laku. Perubahan tingkah laku sebagai hasil belajar dalam pengertian luas mencakup bidang kognitif, afektif,dan psikomotorik (Sudjana, 2009 :3).

Sebagai solusi alternatif yang dianggap efektif dan efisien dalam meningkatkan hasil belajar siswa adalah dengan melakukan penelitian tindakan kelas. Untuk dapat mengatasi masalah tersebut diatas, maka peneliti menerapkan metode kooperatif tipe jigsaw. Jigsaw didesain selain untuk meningkatkan rasa tanggung jawab siswa secara mandiri juga dituntut saling ketergantungan yang positif (saling memberi tahu) terhadap teman sekelompoknya. Selanjutnya diakhir pembelajaran, siswa diberi kuis secara individu yang mencakup topik materi yang dibahas.

Pembelajaran cooperative adalah rangkaian kegiatan belajar yang dilakukan oleh siswa dalamkelompok-kelompok tertentu untuk mencapai tujuan pembelajaranyang telah dirumuskan (Sanjaya, 2008: 241). Prinsip dasar pembelajaran kooperatif adalah siswa membentuk kelompok kecil dan saling mengajar sesamanya untuk mencapai tujuan bersama. Menurut Suprijono (2011:54), pembelajaran kooperatif dianggap 
Mangatur Silitonga: Peningkatan Aktivitas dan...

lebih diarahkan guru untuk membantu siswa menyelesaikan masalah yang dimaksud.

Tujuan

dibentuknya

kelompok kooperatif adalah untuk memberikan kesempatan kepada siswa agar dapat terlihat secara aktif dalam proses berfikir dalam kegiatan belajar mengajar. Jigsaw adalah model pembelajaran kooperatif dengan siswa dalam belajar kelompok kecil terdiri dari 4-6 orang secara heterogen. Teknik ini serupa dengan pertukaran antar kelompok. Bedanya setiap siswa mengajarkan sesuatu. Ini merupakan alternatif menarik bila ada materi belajar yang disegmentasikan. Setiap siswa mempelajari setiap bagian yang bila digabungkan akan membentuk pengetahuan yang padu (Silberman, 2004:65).

Jigsaw didesain selain untuk meningkatkan rasa tanggung jawab peserta didik secara mandiri juga dituntut saling ketergantungan yang positif terhadap teman sekelompoknya selanjutnya diakhiri pembelajaran. Peserta didik diberi kuis secara individu yang mencakup materi setiap peserta didik terhadap anggota tim memberikan informasi yang diperlukan dengan tujuan agar dapat mengerjakan kuis dengan baik (Slavin, 2005 :237).

Dalam konsep jigsaw, semua siswa harus bisa mendapatkan kesempatan dalam proses belajar mengajar supaya semua pemikiran siswa dapat diketahui (Amri dan Ahmadi, 2010: 180). Kelebihan strategi ini yaitu dapat melibatkan seluruh siswa dalam belajar dan sekaligus mengajarkan kepada orang lain (Zaini, dkk. 2008 :56).

Hal yang senada dengan pendapat diatas adalah Penelitian Setyaningrum (2012) berjudul "Penggunaan Model Pembelajaran Kooperatif Tipe Jigsaw Untuk Meningkatkan Kualitas Pembelajaran IPA Pada Siswa Kelas V Sekolah Dasar Negeri Tegalsari 08 Kota Tegal". Dari penelitiannya membuktikan bahwa penggunaan model pembelajaran kooperatif tipe jigsaw dapat meningkatkan kualitas pembelajaran IPA kelas V Pada siklus I diperoleh nilai rata-rata 73,95 sedangkan pada siklus II menungkat menjadi 81,84 . Persentase aktivitas belajar siswa pada siklus I sebesar 74,6 kemudian meningkat menjadi 81,47 pada siklus II.

Berdasarkan permasalahan tersebut maka alternatif pendekatan pembelajaran yang tepat pada mata pelajaran matematika yaitu dengan metode kooperatif tipe jigsaw. Melalui metode kooperatif tipe jigsaw diharapkan dapat meningkatkan rasa tanggung jawab siswa terhadap pembelajarannya sendiri dan juga pembelajaran orang lain.

Tujuan dari penelitian ini adalah untuk meningkatkan hasil belajar matematikakhususnya materi operasi hitung bilangan bulat pada siswa kelas VIII-1 SMP Negeri 3 Tebing Tinggi melalui metode kooperatif tipe jigsaw. 


\section{METODE PENELITIAN}

Penelitian ini dilaksanakan pada bulan Agustus sampai dengan bulan September 2016. Penelitian ini dilaksanakan dalam 2 siklus. Peneliti mengambil lokasi penelitian tindakan kelas di SMP Negeri 3 Tebing Tinggi.

Subjek penelitian adalah siswa kelas VIII-1SMP Negeri 3 Tebing Tinggi dengan jumlah siswa sebanyak 37 orang dengan 19 orang laki-laki dan 18 orang perempuan. Sumber data yang digunakan adalah siswa kelas VIII-1 SMP Negeri 3 dan teman sejawat. Pada Penelitian tindakan kelas data yang dikumpulkan dapat berbentuk kuantitatif maupun kualitatif. Data kuantitatif yang berupa nilai dianalisis dengan menggunakan analisis deskriptif komparatif yaitu membandingkan nilai tes kondisi awal, nilai tes setelah siklus I dan II yaitu nilai dari hasil ulangan harian siswa kelas VIII-1SMP Negeri 3 pada siklus I dan II.

Metode penelitian yang digunakan dalam penelitian ini adalah Classroom Action Research atau penelitian tindakan kelas.. Model penelitian tindakan kelas yang digunakan peneliti adalah sistem spiral refleksi diri yang dikembangkan oleh Kemmis dan Taggart yang dimulai dengan perencanaan, tindakan, pengamatan, dan refleksi. Masing-masing siklus terdiri dari dua kali pertemuan yaitu sebagai berikut:

\section{Perencanaan}

Pada tahapan ini dilakukan berbagai persiapan dan perencanaan tindakan yang meliputi: menyusun skenario pembelajaran berupa Rencana Pelaksaan Pembelajaran, mempersiapkan media pembelajaran dan alat observasi, dan membuat instrumen untuk evaluasi yang berupa soal tes tertulis. Selain mempersiapkan hal-hal tersebut, untuk dapat melaksanakan penelitian ini dengan tujuan yang jelas peneliti juga perlu menetapkan indikator ketercapaian dalam penerapan metode kooperatif tipe jigsaw.

\section{Pelaksanaan}

\section{Siklus I}

Guru yang melakukan pembelajaran di dalam kelas dengan menggunakan panduan perencanaan yang telah dibuat. Siklus I dilakukan pada tanggal 23 Agustus 2016. Kegiatan guru pada awal pembelajaran adalah: (1) Membuka pelajaran. (2) Mengaitkan topik dengan pengetahuan awal siswa dengan cara tanya jawab. (3) Menyampaikan tujuan dan langkahlangkah pembelajaran. (4) Menyampaikan gambaran inti pembelajaran.

Adapun tindakan guru pada kegiatan inti adalah: (1) Membagi siswa atas 4 kelompok dimana satu kelompok terdiri dari 6 siswa (2) Menginformasikan tentang sub materi yang dibahas kelompok ahli (3) Memberikan nama pada masingmasing kelompk asal 4) Menentukan 
masing-masing anggota kelompok yang menjadi kelompok ahli 5) Mengintruksikan kepada kelompok ahli untuk berkumpul 6) Mengintruksikan masing-masing kelompok ahli untuk mendiskusikan topik yang mereka diskusikan masing-masing kelompok ahli 70 Mengintruksikan siswa supaya kembali kedalam kelompok asal (8) Masing-masing kelompok ahli menjelaskan pengetahuannya yang didapat kepada kelompok asal secara bergantian.

\section{Siklus II}

Guru

melakukan

pembelajaran di dalam Guru melakukan pembelajaran di dalam kelas dengan menggunakan panduan perencanaan yang telah dibuat. Siklus I dilakukan pada tanggal 30 Agustus 2016. Pelaksanaan tindakan pada siklus II ini juga sama dengan siklus I namun mengalami perbaikan menuju lebih baik lagi.

Adapun tindakan guru pada kegiatan inti adalah: (1) Membagi siswa atas 4 kelompok dimana satu kelompok terdiri dari 6 atau 7 siswa (2) Menginformasikan tentang sub materi yang dibahas. 4) Menentukan masing-masing anggota kelompok yang menjadi kelompok ahli 5) Mengintruksikan kepada kelompok ahli untuk berkumpul 6) Mengintruksikan masing-masing kelompok ahli untuk mendiskusikan topik yang mereka diskusikan masing-masing kelompok ahli 70 Mengintruksikan asiswa supaya kembali kedalam kelompok asal (8)
Masing-masing kelompok ahli menjelaskan pengetahuannya yang didapat kepada kelompok asal secara bergantian. Tindakan guru pada kegiatan akhir adalah: (1) Mengevaluasi kemampuan siswa dengan memberikan pertanyaan atau kuis secara individu (2) Mengadakan tes hasil belajar.

\section{Observasi/Pengamatan}

Guru/Peneliti sekaligus sebagai observator dibantu oleh dua orang Guru lainnya melakukan observasi/pengamatan terhadap semua kejadian pada PBM untuk dijadikan acuan dalam membuat catatan (Vignette) dan pengisian lembar observasi yang telah dibuat selama proses pembelajaran. Dalam kegiatan pembelajaran, peneliti melakukan pengamatan dengan pengambilan data hasil belajar dan kinerja siswa. Hal tersebut antara lain:

a. Kegiatan siswa selama kegiatan pembelajaran Matematika

b. Kreatifitas dan tugas siswa secara individu maupun kelompok.

\section{Refleksi}

Peneliti mengkaji, melihat dan mempertimbangkan hasil atau dampak dari tindakan yang dilakukan berdasarkan lembar pengamatan yang diisi oleh pengamat. Kegiatan pada tahap refleksi meliputi kegiatan menganalisis, memahami dan membuat kesimpulan berdasarkan hasil observasi setiap siklus. 
menemukan kelebihan dan kelemahan tindakan perbaikan pembelajaran. Hasil analisis data yang dilaksanakan pada tahap ini akan dipergunakan untuk menemukan kelebihan dan kelemahan diri dalam merancang dan melakukan tindakan sebagai acuan.

Instrumen yang digunakan dalam penelitian ini adalah pedoman observasi, test hasil belajar, dan wawancara. Data aktivitas belajar dan kendala yang dihadapi selama proses pembelajaran dikumpulkan melalui observasi (lembar observasi terlampir). Hal-hal yang akan diobservasi adalah kegiatan lisan, kegiatan metrik, kegiatan emosional. Data hasil observasi, dan data hasil wawancara yang jenis datanya berupa pernyataan-pernyataan, dianalisis dengan menggunakan teknik analisis statistik deskriptif.

Metode pengumpulan data penelitian ini adalah tertulis dan observasi. Penelitian ini dikatakan berhasil apabila siswa telah memperoleh nilai ketuntasan secara klasikal minimal $85 \%$ dari jumlah siswa dengan rumus sebagai berikut:

Persentase Ketuntasan klasikal = Jumlah siswa yang tuntas $\times 100 \%$ Jumlah siswa yang mengikuti tes

\section{HASIL PENELITIAN DAN PEMBAHASAN}

Berdasarkan observasi awal pada pra siklus, diketahui hasil belajar siswa pada pra siklus dalam memahami materi pelajaran agak sulit. Pada saat sebelum pembelajaran metode jigsaw diterapkan. Pembelajaran bersifat satu arah dan didominasi oleh guru. Guru langsung memberikan konsepkosep pembelajaran tanpa dilibatkannya siswa untuk menemukan-konsep konsep pembelajaran, siswa kebanyakan diam, bahkan ada siswa yang bercerita dengan teman sebangkunya dan dak adanya umpan balik refleksi saat pembelajaran.

Tes awal dilaksanakan untuk mengetahui kemampuan dasar siswa pada materi yang diajarkan. Tes awal juga dilaksanakan untuk menentukan penelitian dapat dilanjutkan atau tidak, hal ini dapat dilihat dari hasil yang diperoleh dari tes awal adalah dari 37 siswa, hanya 23 siswa yang memenuhi nilai ketuntasan belajar (nilai 70) dan masih terdapat 14 siswa yang tidak memenuhi nilai ketuntasan. Sehingga presentase siswa yang lulus hanya $62,16 \%$ dan masih terdapat $37,84 \%$ siswa yang mendapat nilai dibawah nilai ketuntasan dengan nilai rata-rata adalah 70,5.

Hasil penelitian tindakan
kelas pengamatan yang dilakukan oleh mitra kolaborasi dan peneliti pada aktivitas guru dan siswa melalui penerapan metode kooperatif tipe jigsaw pada mata pelajaran IPA kelas VIII-1SMP Negeri 3 Tebing Tinggi dapat dilihat pada Tabel 1 yaitu sebagai berikut: 
Tabel 1. Peningkatan Hasil Belajar Siswa Pra Siklus, Siklus I dan II

\begin{tabular}{|c|c|c|c|}
\hline \multicolumn{3}{|c|}{ Peningkatan Hasil Belajar } & \multirow[b]{2}{*}{ Keterangan } \\
\hline $\begin{array}{c}\text { Pra } \\
\text { Siklus }\end{array}$ & Siklus I & $\begin{array}{c}\text { Siklus } \\
\text { II }\end{array}$ & \\
\hline 23 & 27 & 33 & $\begin{array}{l}\text { Jumlah } \\
\text { Siswa } \\
\text { Lulus }\end{array}$ \\
\hline 62,16 & 72,97 & 89,18 & $\begin{array}{l}\text { Persentase } \\
\text { Ketuntasan } \\
\text { Belajar } \\
(\%)\end{array}$ \\
\hline $\begin{array}{l}\text { Tidak } \\
\text { Tuntas }\end{array}$ & $\begin{array}{l}\text { Tidak } \\
\text { Tuntas }\end{array}$ & Tuntas & $\begin{array}{l}\text { Ketuntasan } \\
\text { Secara } \\
\text { Klasikal }\end{array}$ \\
\hline
\end{tabular}

Berdasarkan pengamatan peneliti dari tindakan pra siklus, siklus I dan II terjadi peningkatan hasil belajar pada jumlah siswa dan persen ketuntasan belajar secara klasikal. Pembelajaran siklus I menggunakan metode kooperatif tipe jigsaw menunjukkan adanya peningkatan hasil belajar siswa. Hasil analisis data nilai keterampilan siswa mengenai materi pelajaran pada tes siklus II dan menunjukkan bahwa persentase hasil tes siswa yang belajar tuntas naik sebesar $16,21 \%$ dibandingkan dengan siklus I.

Hasil belajar siswa padasiklus I oleh siswa kelas VIII-1 pada pelajaran IPA diperoleh nilai ratarata72,4. Dari 37 orang siswa yang mengikuti ujian pada pelajaran matematika hanya 27 orang siswa atau $72,97 \%$ yang berhasil mendapatkan nilai $\geq 70$. Hasil tersebut menunjukkan bahwa pada siklus pertama secara klasikal siswa belum tuntas belajar, karena siswa yang memperoleh nilai $\geq 70$ hanya sebesar 72,97 \% lebih kecil dari persentase ketuntasan yang dikehendaki yaitu sebesar $85 \%$.

Kurang berhasilnya pembelajaran pada siklus I dikarenakan siswa masih merasa asing dengan penggunaan metode pembelajaran yang baru ini. Selama ini, siswa hanya belajar menggunakan metode diskusi biasa. Pada model pembelajaran kooperatif tipe jigsaw ini siswa mendapatkan tugas dan tanggung jawab yang berbeda-beda dalam mempelajari materi. Namun, siswa masih belum sepenuhnya mengetahui dengan jelas apa yang menjadi tugas dan tanggung jawab itu. Penyampaian materi kurang maksimal sehingga berakibat pada rendahnya hasil belajar pada siklus I.

Aktivitas belajar pada siklus I siswa belum menunjukkan hasil yang baik meskipun terjadi peningkatan hasil belajar. Hal ini dibuktikan masih banyak siswa yang bergurau bahkan tidak melaksanakan tugasnya untuk mempelajari materi dan menyampaikannya kepada teman satu kelompok. Hanya beberapa siswa yang terlihat serius dalam mengikuti proses pembelajaran tersebut. Kegiatan diskusi dalam kelompok masih didominasi oleh siswa-siswa yang cerdas saja. Kondisi seperti ini terjadi karena pembelajaran kooperatif merupakan hal yang baru bagi siswa belum dapat sepenuhnya memahami dan tanggung jawabnya pada kelompok.

Dengan penerapan metode kooperatif tipe jigsaw dapat 
meningkatkan hasil belajar siswa kelas VIII-1 SMP Negeri 3 Tebing Tinggi. Nilai yang masih rendah disebabkan karena siswa belum terbiasa dengan metode kooperatif tipe jigsaw dan siswa perlu beradaptasi dengan metode tersebut. Hasil tersebut menggambarkan perlu adanya suatu tahapan selanjutnya untuk memperbaiki hasil belajar agar target yang diharapkan dapat tercapai. Untuk siklus II kegiatan mengerjakan latihan soal ini diharapkan semakin baik karena siswa sudah terlatih dan terampil untuk mengerjakan soal latihan pada materi yang dipelajari.

Hasil ulangan siklus II, siswa pada pelajaran matematika di kelas VIII-1 sudah tergolong baik, yaitu memperoleh rata-rata 73,51 dari Kriteria Kelulusan Minimal (KKM) yang harus dicapai siswa adalah 70 . Dari 37 orang siswa yang mengikuti ujian pada pelajaran IPAsebanyak33 siswa atau $89,18 \%$ yang berhasil mendapatkan nilai di atas nilai 70 . Hasil tersebut menunjukkan bahwa pada siklus kedua secara klasikal siswa sudah tuntas belajar, karena siswa yang memperoleh nilai $\geq 70$ hanya sebesar $89,18 \%$ lebih besar dari persentase ketuntasan yang dikehendaki yaitu sebesar $85 \%$.Aspek yang dianggap kurang merupakan suatu kelemahan yang terjadi pada siklus I dan akan dijadikan bahan kajian untuk refleksi dan revisi yang akan dilakukan pada siklus II.

Data hasil belajar pada siklus II dinyatakan bahwa terjadi peningkatan yang signifikan pada hasil belajar. Hal tersebut didukung berdasarkan jumlah siswa yang mengalami peningkatan hasil belajar. Sebanyak 33 orang siswa tuntas secara klasikal dari 37 siswa setelah dilakukan tes akhir siklus II hasil belajarnya meningkat. Pelaksanaan pembelajaran pada siklus II ini telah dapat dikatakan berhasil, seiring dengan berhasilnya siswa dengan mendapatkan rata-rata nilai yang memuaskan. Rata-rata nilai yang diperoleh siswa mampu menjelaskan bahwa materi yang dibahas yang mereka pelajari dengan metode kooperatif tipe jigsaw dapat diterima dengan baik.

Hasil observasi kegiatan siswa sudah termasuk ke dalam kategori baik, berarti disini peneliti sudah mulai memilimalisir kekurangan sebelumnya. Kegiatan siswa dalam memecahkan masalah dalam kelompok, berdiskusi dengan teman sebangku, dapat berupa saling berbagai jawaban, mempresentasikan hasil diskusi dengan teman sebangkunya di depan kelas mengalami peningkatan dari siklus sebelumnya.Sehingga dianggap sudah cukup baik oleh peneliti dan pengamat.

Saat pelaksanan siklus II, aktivitas belajar siswa telah mengalami peningkatan. Hal ini tampak pada saat mereka melakukan diskusi kelompok. Masing-masing siswa sudah mengetahui dan melaksanakan tugasnya dengan baik. Saat diskusi kelompok, semua siswa mempelajari materi secara bersama- 
sama dengan baik. Ketika para siswa ditugaskan untuk menyampaikan materi yang telah dipelajari, maka secara bergantian menjelaskan dengan baik kepada teman satu kelompoknya. Siswa dalam satu kelompok dapat kerjasama dengan baik saat mengerjakan LKS. Masingmasing siswa berperan dakan kegiatan tersebut sehingga diskusi sudah tidak lagi didominasi oleh siswa-siswa yang cerdas saja.

Sikap dan respon siswa mulai senang terhadap pembelajaran matematika dengan menggunakan metode kooperatif tipe jigsaw. Oleh karena itu tidak perlu pengulangan siklus. Maka dari itu tidak perlu dilanjutkan ke siklus selanjutnya karena sudah dianggap berhasil dan memenuhi kriteria penilaian secara klasikal.

Dari kegiatan pembelajaran yang telah berlangsung dengan penerapan metode jigsaw, maka tujuan pembelajaran yaitu untuk dapat mengatasi kesulitan belajar siswa dan siswa untuk lebih aktif, kreatif dalam proses belajarmengajar. Model pembelajaran kooperatif tipe jigsaw menekankan pada kinerja siswa, baik secara individu maupun kelompok. Dalam kelompok asal, masing-masing siswa mempunyai tanggung jawab yang berbeda terhadap materi yang dipelajari. Hal ini sesuai dengan pendapat Slavin (2005): Jigsaw didesain selain untuk meningkatkan rasa tanggung jawab peserta didik secara mandiri juga dituntut saling ketergantungan yang positif terhadap teman sekelompoknya selanjutnya diakhiri pembelajaran. Peserta didik diberi kuis secara individu yang mencakup materi setiap peserta didik terhadap anggota tim memberikan informasi yang diperlukan dengan tujuan agar dapat mengerjakan kuis dengan baik.

Selain itu, metode pembelajaran kooperatif tipe jigsaw ini juga mampu meningkatkan performansi guru. Pemggunaan metode ini membuat guru lebih matang dalam menyusun RPP. Guru juga lebih inovatif dan kreatif dalam menyusun langkah-langkah pembelajaran sesuai dengan tahapan jigsaw. Peran guru yang demikian membuat proses pembelajaran menjadi lebih menarik bagi siswa dan siswa dapat bertanggungjawab terhadap tersampaikannya materi kepada teman pada tiap kelompoknya. Praktik guru dalam mengajar menjadi lebih bervariasi karena tidak monoton dengn metode ceramah saja.

\section{Pembahasan}

Berdasarkan hasil yang didapat dari setiap siklus proses pembelajaran yang optimal, hal ini ditunjukkan dengan meningkatnya penguasaan materi dan hasil belajar siswa. Oleh karena itu dapat disimpulkan bahwa proses pembelajaran dengan penerapan metode kooperatif tipe jigsaw sangat sesuai dengan mata pelajaran matematika khususnya materi operasi hitun bilangan bulat. Maka dari itu, Penelitian Tindakan Kelas 
(PTK) ini bisa dikatakan berhasil karena hasil peningkatan proses pembelajarannya optimal.

Gambaran peningkatan ketuntasan belajar siswa mata pelajaran IPA yang diperoleh setelah melakukan penelitian dengan menggunakan metode kooperatif tipe jigsaw terlihat pada diagram berikut:

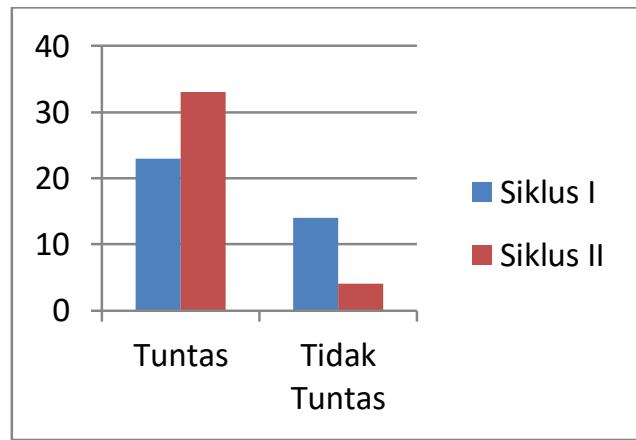

\section{Grafik 1. Peningkatan Ketuntasan} Belajar

\section{SIMPULAN}

Dari hasil penelitian yang diperoleh dapat disimpulkan bahwa penerapan metode kooperatif tipe jigsaw berdampak positif dalam meningkatkan aktivitas dan hasil belajar IPA pada siswa kelasVIII-1 SMP Negeri 3 Tebing Tinggi. Hal tersebut dapat dilihat dari peningkatan persentase ketuntasan belajar siswa setiap siklusnya.Pada siklus I sebesar 72,97 \%dan meningkat sebesar $89,18 \%$ pada siklus II.

\section{DAFTAR RUJUKAN}

Amri, Sofian, dan Ahmadi. 2010. Konstruksi Pengembangan Pembelajaran Pengaruhnya Terhadap Mekanisme dan
Praktik Kurikulu. Jakarta: Prestasi Pustakarya.

Muslichah, A. 2006. Penerapan Pendekatan Sains-TeknologiMasyarakat. Jakarta: Departemen Pendidikan Nasional.

Setyaningrum, D. 2012. Penggunaan Model Pembelajaran Kooperatif Tipe Jigsaw Untuk Meningkatkan Kualitas Pembelajaran IPA Pada Siswa Kelas V Sekolah Dasar Negeri Tegalsari 08 Kota Tegal. Skripsi. Universitas Negeri Malang

Silberman, M. 2004. 101 Strategi Pembelajaran Aktif (Active Learning). Bandung: Nusa Media.

Slavin, R. 2005. Cooperative Learning. Bandung: Nusa Media.

Sudjana, N. 2009. Pendidikan Hasil Proses Mengajar. Bandung, Remaja Rosdakarya.

Suprijono, A. 2011. Cooperative Learning Teori dan Aplikasi PAIKEM. Yogyakarta: Pustaka Belajar.

Zaini, Hisyam, dkk. 2008. Strategi Pembelajaran Aktif. Yogyakarta. Pustaka Insan Madani. 